\title{
AN ERROR ANALYSIS OF STUDENTS' TRANSLATING TENSES AT SMK PASUNDAN 2 CIANJUR
}

\author{
Wulan Dara Andarisa
}

Wulandararisa@gmail.com

\begin{abstract}
The title of this paper is "An Error Analysis of Students' Translating Tenses". The goal of this research are to find out the kind of errors do the students commonly make in English-Indonesian translation, especialy in tenses and to find out the causes of their errors in English-Indonesian translation tenses. The method that the writer used in this research was descriptive qualitative as its method to analyze and describe entire data. The research participants of this study was the member of grade XII T-Eind's Class at SMK 2 Pasundan Cianjur. The member of partisipants consisits of 47 male students. The data was taken from translation test and interview. After getting entire the data, then it was analyzed and describe it. Then after analyzing them, the writer found the kind of errors when students' translating tenses. such as translation verb, translation to be, translation of "be", translation of plural word and the unsuitable dictions of transfer the words from SL to TL in tenses. Based on the analysis the error when students translated verb in tenses consists of 83 erors from 423 data, the error when students translated to be in tenses consists of 53 errors from 423 data, the error when students translate "be" in tenses consists of 35 errors from 423 data, the error when translation plural of word consist of 8 errors from 423 data, and the unsuitable diction of translfer the word from SL to Tl in tenses consists of 37 erors from 423 data. Moreover the causes of students errors when they translated tenses are translation used word to word method, the students have not a good source language (English language), the students have not a good comprehension of vocabulary and the students not understand about tenses (present continuous tense, past continuous tense and future countinuous tense). Some suggestions was given to develop the learners' competence and the reseacher hoped this study benefit for others reseachers as futhermore reference.
\end{abstract}

Keywords: translating, tenses, an error analysis.

\section{INTRODUCTION}

Language is a means of communication that is used to transfer information, ideas, and feelings from one person to others. It is used to communicate both in written and spoken. Considering the importance of the 
language, our government has drawn up English as a foreign language that should be mastered by the students.

According to Alwasilah (2013), "English is recognized as the most significant foreign language in Indonesia since 1980s and this has witnessed a tremendous growth since the early 1990s". However, since English is only a foreign language, there are a lot problems found in Engish language learning. For examples teaching and learning process is boring, environment, tool of learn, and in Indonesia the students begin learn English by writing not listening. Teachers are also faced with many problems in the course of their duties in teaching English as foreign language especially with overcrowded classrooms and inadequete continuous development programs.

Research by Syamsinar and Johari (2014) support English language has been seen as a good medium of communication in Indonesia. Apart from the fact that it has been adopted as a teaching language in higher Institution of learning, it is also being considered as an enhancement for social status. All in all English language has been seen as a defacto standard medium of communication all over the world and Indonesia cannot be left out.

English has been considered to be the first foreign language in Indonesia. The term foreign language in the field of language teaching is different from the second language. Foreign language is a language that is not used communication tool in a particular country where the language is taught. In Indonesia, English is a foreign language so translation is one of the difficult things because according to Brislin (1976), "translation is a general term referring to the transfer of thoughts and ideas from one language to another, whether the language is in written or oral form, whether the languages have established orthographies or not; or whether one or both languages is based on signs, as with signs of the deaf'. 
Newmark (1988) stated that translation methods consist of eight methods. One of the methods is Faithful translation. It is translation attempt to reproduce the precise contextual meaning of the original within the constrains of the target language grammatical stuctures. In this research, faithful translation has relationship with tenses translation. Because when students are translating tenses the method of translation that is used is faithful translation or students translate as grammatically.

When students are translating tenses, there are some things happen such as error and mistake. Error can occur for many reasons such as over-generalization, ignorance of rule restriction, incomplete of application rules, and false concept hypothesized.

As we know, tenses is a verb based method used to indicate the time, and sometimes the continuation or completeness, of an action or state in relation to the time of speaking. And when they are translating regular and irregular verb. Sometimes they erroneous when they translate it. Then, an error when students translate tenses always be present because Harmer (1989) said error is the result of incorrect rule learning, language has been stored in the brain incorrectly.

When we talk about error, we may also thinking about mistake, although error and mistake have same meaning in general, they are not exactly the same, it is crucial to make distinction between error and mistake and most of people still misunderstand about the definition of both. According to Corder (1974), "Error Analysis (EA) was an alternative to contrastive analysis, an approach influenced by behaviorism through which applied linguists sought to use the formal distinctions between the learners' first and second languages to predict errors".

In this study, the reseacher talked about an error analysis students translating tenses, the kind of errors do the students commonly make in English-Indonesian translation, especially in tenses and the causes of their errors in English-Indonesian translation tenses.

According to Yule (1998, p.54-58), the different forms of a verb in English are determined in terms of tense and aspect. The latter reveals the way in 
which the situation is perceived or experienced, while the former is related to the location of the situation in time. The simple time-line view, which stands past as yesterday, present as today, and future as tomorrow, seems to induce learners to misunderstand English verb forms.

This research is a rare. So in this papers is very important thing to more analysis. Because translating tenses is very difficult especially to students that conclude English has foreign language for example in Indonesia. And in this study the reseacher will explain about kind of errors do the students commonly make in English-Indonesian translation, especially in tenses. And the causes of their error in Indonesian-English translation, especially in tenses.

The method used qualitative method to describe the characteristic of the data. This type of research gives emphasis on the value of looking on variables in their natural setting where they are commonly found. The research participant of this study is member of grade XII T-Eind' class at SMK 2 Pasundan Cianjur. Because they had gotten the material about tenses.

The reseacher hopes this study can give a concrete contribution for the Departement of English Education to improve the lecturing of translation so that the students are able to eliminate or even omit the errors in translation especially when they translate tenses from English-Indonesian.

\section{THEORETICAL FRAMEWORKS}

\section{Definition of Translation}

Translation is the process transferring meaning in the text from source language to target language. It is the expression in another language (or target language) of what has been expressed in another, source language, preserving semantic and stylistic equivalences. 
The translator should observe equivalent from source language to target language. Translation involves the rendering of source language (SL) text into the target languge (TL) so as to ensure that:

1. The surface meaning of the two will be approximately similar.

2. The structure of the SL will be preserved as closelyas possible, but not so closely that the TL structure will be seriously distorted.

\section{Tenses Part of Grammar}

In grammar, the students are provided with many rules of a language. One of them is tense. Hornby $(1975: 123)$ states that tense is a verb form or series of verb forms used to indicate the time of the action or state. It is important for the students to learn tenses since they have great influence in forming the meaning of sentences.

Tense may indicate whether an activity or state is, was, or will be completed or whether it is, was, or will be in progress over period of time. In grammar tense is a category that expresses time reference. Tense is a verb based method used to indicate the time, and sometimes the continuation or completeness, of an action or statein relation to the time of speaking. The concept of tense is a method that we use to refer to time- past, present, and future. Many languages use tense to talk about time. Other languages have no concept of tense at all, but of course they can still talk about time, using different methods.

\section{Error Analysis}

Error analysis is a type of linguistic analysis that focuses on the errors learners make while using language. The analysis includes a comparison between the errors made in targer languag (TL) and the grammar of the language.

According to Richard, John Platt, Platt define error analysis is an attempts of studying of the error made by language learners to classify the made by language learner and classfy the different types of errors on the basic of the differnt processes 
that were assumed to account for them.Different from the other expert above, Ellis (1995) suggests the steps of learner's erros analysis methodology as follows:

1. Collecting samples of learner language

Collection of errors the nature and quantity of errors is likely to vary depending on whether the data consist of natural, spontaneous language use or careful, elicited language use. i.e. the decision what outputs of the learner's language can be used for the analysis and how to collect the data).

2. Identifying the errors

The way of identifying the errors, e.g. by underlying the errors and using the symbols of correcting code.

3. Describing the errors

The errors can be categorized into groups which are stated according to their origin and presence.

4. Explaining the errors

The calculating and explaining the errors in a suitable way.

5. Evaluating/correcting the errors

This step involves the interpretation of tables, graphs and conclusions.

\section{METHOD}

This research was carried out by using qualitative research. As Bogan and Tylor found that qualitative research is a research procedure wich produces descriptive data in written and oral form, from human and his attitude (cited in setiyadi, 2oo6, p.219)

Moreover Cresswell (1997) found that qualitative research is an inquiry process of understanding based on distinct methodological traditions of inquiry that explore a social or human problem. The researcher build a complex, holistic picture, analyzes 
words, reports detailed views of informants, and conducts the study in a natural setting.

This researcher was main data collection instrument. Data was collected by means of interviewing and translation test. The reseacher was made sense of data by using a descriptive method to analyse it. Chose descriptive qualitative method, because according to Eisher (1991), descriptive qualitative research explaine the problem solving. This research is not only sample colleting the data, but covers data analysis, and interpretation to the research problem.

\section{Participants}

According to Kvale (1996) stated that, "Research participant or participant observation is not simply showing up at a site and writing things down. On the contrary, participant observation is a complex method that has many components. One of the first things that a researcher or individual must do after deciding to conduct participant observations to gather data".

The research participants of this study is the member of grade XII T-Eind's Class at SMK 2 Pasundan Cianjur. The member of partisipants consisits of 47 male students. Why the reseacher chose this class, because they had gotten the material about tenses. Another reason, because they are very active, critical, and have good motivation to learn.

\section{Instruments}

\section{Translation Test}

According to Newmark (1988) a successful translation is one that conveys the explicit and implicit meaning of the source language into the target language as fully and accurately as possible. Can successfully apply a translation, translation skill 
(reading in the source language and writing in the target language) is one of the keys of the succsess. However, to assess translation skills, a translation test that measures the individual's ability to exercise congruity judgment and apply a translation methodology successfully must be used. Translation test is one of the tests in the translation skill, the reseacher will give the subject one of the tests about translating tenses especially in English-Indonesia, it is to know the kind of error students when students' translating the tenses.

\section{Interview}

According to Kvale (1996), "the qualitative research interview as an interview whose purpose is to gather descriptions of the life-world of the interviewee with respect to interpretation of the meaning of the described phenomena". According to Oxnov (2011) in his article stated that interview is a systematic oral technique for obtaining data, directly from an individual. It is a conversation between two or more people, through which information are collected on a particular subject. And in Oxnov's article, he explained the definition of interview according to Dr. S.M.Amunuzzaman, he stated that interview is a very systematic method hy which a person enters deeply into the life of even a stranger and can bring out needed information and data for the research purpose.

\section{Data Analysis}

According to Creswell (1997) stated that, "data analysis is the process of evaluating data using analytical and logical reasoning ro examine each component of the data provided". Analysis refers to breaking a whole into its separate components for individual examination. Data analysis a process for obtaining raw data and converting it into information useful for decision-making by users. Data is collected and analyzed to answer questions, test hypotheses or disprove theories.

In this study, the collected data and classied data were analyzed through several data steps. The first, the wrinter used translation test to research an error students' translating tenses. The second, the writer identifying the errors, the way of identifying the errors, e.g. by underlying the errors and using the symbols of 
correcting code. The third, the writer describing the errors, the errors can be categorized into groups which are stated according to their origin and presence. Moreover, the writer explaining the errors, such as calculating and explaining the errors in a suitable way. The last the writer evaluating/correcting the errors. In data analysis reseacher used interview to receive information about translating tenses.

\section{FINDINGS AND DISCUSSIONS}

\section{An Error Analysis of Translating Present Continuous Tense}

The sentences of present continuous tense:

1. I am living in America at the moment.

2. She is looking for a job.

3. I am studying English at this moment.

Based on the translation data of past continuous tense above, the reseacher find the kinds of error, they are:

1. Translation of to be

Some of the students when translated tobe almost error. Morover based on the data the students translated tobe in present continuous tense "am"to be "adalah", and it is wrong. The record, in the translation of present continuous tense, the students did not translate to be "are,am,is". Because to be in present continuous tense show the time.

\section{Translation of verb}

In the first sentence and in the last sentence of present continuous tense, the students did not have a problem when translate verb in present continuous tense for examples in the words of "living and studying". But in the second language, some of the students error when translated verb, especially in the word of "looking for". And 
18th students translated error. They translated "looking for" be "melihat/ melihat untuk".

3. Used unsuitable diction to transfer the word from source language to target language

The Unsuitable Dictions of Transfer The Word from SL to TL in Present Continuous Tense

\begin{tabular}{|l|l|l|l|l|}
\hline & English & Indonesia & Correct & Sentence \\
\hline & Fooking & $\begin{array}{l}\text { Melihat } \\
\text { untuk/mencari-cari. }\end{array}$ & Mencari & She is looking for a job. \\
\hline & Am & Adalah & - & I am living in America at the \\
& & & & moment. \\
\hline & Is & Adalah & - & She is looking for a job. \\
& & & & I am studying English at this \\
& Am & Adalah & - & moment. \\
\hline
\end{tabular}

Based on the result of analysis above of the kind of errors when students translated past continuous tense, the reseacher made the correct in translation past continuous tanse based on Tiga Puluh Hari Mahir Bahasa Inggris by Roziqin (2011). They are:

The Correct in Translation Present Continuous Tanse 


\begin{tabular}{|c|l|l|}
\hline No & English & Indonesia \\
\hline $\mathbf{1}$ & I am living in America at the moment. & Saya sedang tinggal di Amerika sekarang. \\
\hline $\mathbf{2}$ & She is looking for a job. & Dia sedang mencari pekerjaan. \\
\hline $\mathbf{3}$ & I am studying English at this moment. & Saya sedang belajar bahasa inggris pada \\
& & saat ini. \\
\hline
\end{tabular}

\section{An Error Analysis of Translating Past Continuous Tense}

The sentences of past continuous tense:

1. Andi was sleeping all day.

2. Were we studying English when you came.

3. When the teacher came, they were playing chess.

Based on the translation data of past continuous tense above, the reseacher find the kinds of error, they are:

1. Translation of to be

Some of the students when translated tobe almost error. And based on the data 17th students translated tobe in past continuous tense "was" to be "adalah", and it is wrong. Although based on lexically "was" is "adalah". The record, in the translation of past continuous tense, the students did not translate to be "was or were".

\section{Translation of verb}

The students error when translated verb (Ving) in first sentence "Andi was sleeping all day". In the word of "sleepping", 18th students translated be "tidur" and 1st students translated be "tertidur". In the second sentence, based on the data of translation test above, 18th students translated error of verb (Ving). They translated the word of "studying" be 
"belajar". In the last sentence, based on the data of table above, the 10th students translated error of verb (Ving). They translated the word of "playing" be "bermain".

3. Used unsuitable diction to transfer the word from source language to target language

The Unsuitable Dictions of Transfer The Word from SL to TL in Past Continuous

Tense

\begin{tabular}{|l|l|l|l|l|}
\hline English & Indonesia & Correct & Sentence \\
\hline & All day & $\begin{array}{l}\text { Semua } \\
\text { hari }\end{array}$ & $\begin{array}{l}\text { Sepanjang hari/ } \\
\text { seharian }\end{array}$ & $\begin{array}{l}\text { Andi was sleeping all } \\
\text { day } \\
\text { yesterday. }\end{array}$ \\
\hline & When & Kapan & Ketika & $\begin{array}{l}\text { Were we studying } \\
\text { English, } \\
\text { when you came? }\end{array}$ \\
\hline When & Kapan & Ketika & $\begin{array}{l}\text { When the teacher } \\
\text { came, they } \\
\text { were playing chess. }\end{array}$ \\
\hline
\end{tabular}

Based on the result of analysis above of the kind of errors when students translated past continuous tense, the reseacher made the correct in translation past continuous tanse based on Tiga Puluh Hari Mahir Bahasa Inggris by Roziqin (2011).

They are:

The Correct in Translation Past Continuous Tanse

\begin{tabular}{|c|l|l|}
\hline No & English & Indonesia \\
\hline $\mathbf{1}$ & Andi was sleeping all day yesterday. & Andi sedang tidur sepanjang hari kemarin. \\
\hline
\end{tabular}




\begin{tabular}{|c|l|l|} 
& & \\
\hline $\mathbf{2}$ & $\begin{array}{l}\text { Were we studying English when you } \\
\text { came. }\end{array}$ & $\begin{array}{l}\text { Apakah kami sedang belajar bahasa } \\
\text { inggris ketika kamu datang? }\end{array}$ \\
\hline $\mathbf{3}$ & $\begin{array}{l}\text { When the teacher came, they were } \\
\text { playing chess. }\end{array}$ & $\begin{array}{l}\text { Ketika guru datang mereka sedang } \\
\text { bermain catur }\end{array}$ \\
\hline
\end{tabular}

\section{An Error Analysis of Future Continuous Tense}

The sentences of past continuous tense:

1. She will be cleaning the floor.

2. I shall be working tomorrow morning.

3. 3. We will be pecking fruits.

Based on the translation data of future continuous tense above, the reseacher find the kinds of error, they are:

1. Translation of "be", In the first sentence, some of the students when translated "be" almost error. And based on the data 13th students translated "be" be "menjadi/jadi" and it is wrong. Although based on lexically "be" has mean "menjadi/jadi". In the second sentence, based on the data the 14th students translated "be" be "menjadi". In the last sentence, based on the data 8th students translated "be" in future continuous tense. some of the students translated "be" become "jadi/menjadi".

2. Translation of plurals word. In the last sentence of future continuous tense, based on the analysis in the word of "fruits", some of the students translated "fruits" be "buah". The correct is "buah-buahan" because in the word of "fruits" is plural word because in the end of word exist "s". Based on the data of table, 8th students translated "fruits" be "buah" and it is error translation. 
3. Translation of verb, In the first sentence, based on the data of table above, some of the students translated verb in future continuous tense error. For example, when the students translated "cleaning" be "bersihkan". In the second sentence, based on the data of table above, some of the students translated verb in future continuous tense error. For example, when the students translated "working" be "sedang bekerja". In the last sentence, based on the data of table above, some of the students translated verb in future continuous tense correct. For example, when the students translated "pecking" be "memetik".

4. Used unsuitable diction to transfer the word from source language to target language, Based on the data of translation test above, the reseacher find some of the unsuitable dictions to transfer the word from source language to target language when students translated future continuous tense. They are:

\begin{tabular}{|l|l|l|l|l|}
\hline & English & Indonesia & Correct & Sentence \\
\hline & Tomorrow & Besok pagi & Besok & $\begin{array}{l}\text { I shall be working } \\
\text { tomorrow }\end{array}$ \\
\hline & Fruits & Buah & Buah-buahan & We will be pecking fruits. \\
\hline
\end{tabular}

Based on the result of analysis above of the kind of errors when students translated future continuous tense, the reseacher made the correct in translation future continuous tanse based on Tiga Puluh Hari Mahir Bahasa Inggris by Roziqin (2011). They are:

The Correct in Translation Future Continuous Tanse

\begin{tabular}{|c|l|l|}
\hline No & English & Indonesia \\
& & \\
\hline
\end{tabular}




\begin{tabular}{|c|l|l|} 
& She will be cleaning the floor. & Dia akan membersihkan lantai. \\
\hline 2 & I shall be working tomorrow. & Saya akan bekerja besok. \\
& & \\
\hline 3 & We will be pecking fruits. & Kami akan memetik buah-buahan. \\
& & \\
\hline
\end{tabular}

\section{CONCLUSION}

Thus the present study has made an attempt to analyze the common errors committed by the participants. The errors are taken from the student's class room translating. In this study, the reseacher analyzed the kinds of errors do the students commonly make in English-Indonesian translation, especialy in tenses and the causes of their errors in English-Indonesian translation tenses.

Furthermore, based on the fact above, it is known that the students mostly made errors in the sentence that have different meaning. Even all of students know the meaning of word that would be translated, but they did not know the suitable diction to transfer the meaning from source language to target language. The causes of errors based on the analysis are translation used word to word method, the students have not a good source language (English language), the students have not a good comprehension of vocabulary and the students not understand about tenses (present continuous tense, past continuous tense and future continuous tense).

\section{REFERENCES}

Brislin, Richard W, ed. (1976). Translation: Applications and Research. New York; Gradner Press Inc.

Creswell, J.W. (1997). Qualitative Inquiry and Research Design Choosing Among Five Traditions. California: Sage Publications, Inc.

Eisner, E.W. (1991).The Enlightened Eye: Qualitative Inquiryand the Enhancement of Educational Practice. New York: Macmilan. 
Ellis, Rod. (1995). The Study of Second Language Acquisition. Oxford: Oxford University Press.

Hornby, AS. (1975). Guide to Patterns and Usage in English. Oxford: Oxford University Press

Jeremy, Harmer. (1989). The Principle of Language Learning and Teaching. New York: Prentice Hall Regents.

Kvale, S. (1996).Interviews: An Introduction to Qualitative Research Interviewing. California: Sage Publications, Inc.

Newmark, Petter. (1988). A Textbook of Translation. New York: Sanghai Foreign Lnguage Education Press

Stephen Pit. Corder. (1974). Technique in Applied Linguistic, An Introduction to Second Language Acquisition Research. London: Oxford University Press.

Setiadi, A.B. (2006). Metode Penelitian untuk Pengajaran Bahasa Asing. Yogyakarta: Graha Ilmu

Yule, George. (1998). Explaining English Grammar. Oxford, UK: Oxford University Press 